\title{
Identifying competencies for future graphic design graduates in Malaysia: A Delphi study
}

\begin{abstract}
Traditionally, graphic design (GD) education focuses on the training of technical production skills to prepare graduates for entry-level employment. However, due to the new challenges and the expanding opportunities of emerging practices, GD graduates are expected to master a wide range of additional competencies beyond traditional scope. The study aims to identify the competencies required by future GD graduates in the context of Malaysia. A two-round modified Delphi technique was used to gain consensus from a panel of experts consisted of design educators and industry practitioners regarding the competencies needed by the graduates for effective work performance. A total of 108 competencies were generated. All accepted competencies were ranked 'very important' and 'extremely important' by at least 75 percent of the respondents in Round Two. These competencies could be classified into 29 subdomains under five components, i.e., cognitive competence, functional competence, personal competence, ethical competence, and meta-competencies. The findings of this study are useful for enhancing the education and employability of graphic designers as they provide a common vocabulary to relevant stakeholders about the standards of performance for new entrants to the GD profession.
\end{abstract}

\section{KEY WORDS}

modified Delphi technique, graphic design graduates, cognitive competence, functional competence, personal competence, ethical competence, and meta-competencies, Malaysia

\author{
Shaw-Chiang Wong ${ }^{1}$ \\ Muhammad Zaffwan Idris ${ }^{2}$ \\ Wee-Chuen $\operatorname{Tan}^{1}$ \\ ${ }^{1}$ Raffles University, Faculty of Art \\ and Design, Johor Bahru, Malaysia \\ ${ }^{2}$ Universiti Pendidikan Sultan Idris, \\ Faculty of Art, Computing and \\ Creative Industry, \\ Tanjong Malim, Malaysia
}

Corresponding author: Wong Shaw Chiang e-mail:wongshawchiang@ raffles-university.edu.my

First received: 22.3.2021.

Accepted: 4.06.2021.

\section{Introduction}

The demands on the professional practice of GD in the $21^{\text {st }}$ century bear little resemblance to those of the past (Heller, 2015). Traditionally, graphic designers have often been viewed as 'craftsmen' or 'decorators' who focus on 'the making of things and beautiful things' (American Institute of Graphic Design (AIGA), 2015a). Rapid development in technology and industry has expanded the scope and content of graphic designers' work (Dziobczenski \& Person, 2017; Harland, 2016). Nowadays, graphic designers are found to work in areas such as service design, strategic planning, innovation management, branding, and technology development (Davis, 2017). Approaches and strategies in design have also been gradually shifted from designer-oriented to user-centred, intuition-based to research-driven, and single-disciplinary work to interdisciplinary collaboration (Muratovski, 2016). To meet the changing demands in practice, designers are required to adapt and acquire a new range of competencies in a broader range of disciplines and fields (Kiernan \& Ledwith, 2014).

However, there is little updated information on the current employment requirements of graphic designers in education (Cheung, 2016; Davis, 2015; Marks, 2015; Swanson, 2015). To date, technical production skills, including strategies in visual composition, principles of typesetting, and understanding of print processes remain the training priorities in the GD programmes of many universities (Davis, 2005, 2017; Frascara, 1988). Consequently, students are mostly ill-prepared for the 
skills, knowledge, and abilities needed to deal with the changing demands in design practice upon graduation (Heller, 2005b; Hsieh, Guan \& Wu, 2010) and eventually "end up in roles where they design according to a set of given instructions" (Lim, 2015, p.58). Since the students are trained to fulfil yesteryears' needs, there is a growing concern about whether formal GD education is still necessary (Chiang, Idris \& Chuen, 2018). Such concern is raised because there is an increasing number of 'selftaught' or 'informally trained' designers who learn design software independently themselves and work effectively as 'graphic designers' in the industry (Okyere, 2017).

In general, there are no prescribed professional standards to guide the development of academic programmes in GD at university level (Cheung, 2011; Chiang, Idris \& Chuen 2019). Although GD programmes offer more or less the same introductory courses, students are taught differently from university to university (Wilson, 2014). Levels of teaching excellence and graduates' quality also vary between universities (Debbie, 2011). As highlighted by Heller (2015), "Unlike degree programs for professions governed by established standards and standardized test (i.e., law, medicine, engineering, psychology, economics), graphic design - which does not, and perhaps may never, necessitate broad-tested certification - has very few strict curriculum conventions and hardly any blanket requirements (other than "knowing" the computer and being "fluent" in type)" (p. 12). Since the job scope of graphic designers today is far more complicated and broader than before, the absence of prescribed professional standards creates difficulties in developing the most relevant curricula for those who wish to practice in the field of GD (Higgins, 2008).

The conflict between educators and industry practitioners have always been an issue in the GD field (Bridges, 2013; Dziobczenski \& Person, 2017). Question about what skills and knowledge should be taught to best prepare the students for their professional careers remains a popular topic of debate and discussion between both parties. Wang's (2006) study exemplified this and found out that while industry practitioners focused more on mastery of competencies that are more task-oriented, design educators emphasized more on knowledge-based competencies. Cheung's (2016) study also suggested that "the criteria of competence held by design academia and those held by industry [in Hong Kong] were different: the differences between broader objective and narrower subjective business measures" (p. 37). However, most educators and industry practitioners involved in the study failed to aware of this 'blind spot'. As a result, a 'knowledge gap' seems to appear when university students enter the actual workplace. Cheung's (2016) findings echoed the concern of Eraut (2007) that the primary challenge university graduates experience during the early period of professional learning and development is the "different types of discourse and epistemologies" (p.116). In this case, educators and practitioners need to come to some 'agreements' regarding the competencies expected for new entrants to the GD profession to fill the 'knowledge gap' and thereby enhancing the educational and employability process (Chiang, Idris \& Chuen, 2018) as well as strengthening the status of GD as an academic and professional discipline (Dziobczenski \& Person, 2017).

Although a number of studies had been conducted to identify the knowledge, skills, traits, and abilities required by GD graduates in different geographical regions (e.g., Bridges, 2013; Cheung, 2016; Dharavath, 2003; Dziobczenski \& Galeotti, 2017; Dziobczenski et al., 2018; Hsieh, Guan \& Wu, 2010; Wang, 2006; Wilson, 2014), ethics and values are being paid relatively less explicit attention in these studies. However, design scholars (e.g., Berman, 2009; Heller \& Vienne, 2003; McCollam, 2014; Perkins, 2011) and design associations (e.g., AIGA, 2010; WREGA, 2012; International Council of Design (ico-D), 2011; GDC, 2012) have highlighted their significance to professional practice and development in the GD field. This means that both ethics and values are important competencies that should be introduced to students while studying at university.

Both Bridges (2013) and Wang (2006) suggested that due to the rapid advancement of technology and expansion of global consumer market, more studies on GD competencies should be done in different geographical regions to ensure up-to-date curriculum is always ready for various stakeholders. Up to the best notice of the authors of this study, very few related studies have been done in developing countries such as Malaysia. Therefore, this study aims to identify the essential competencies that should be possessed by future GD graduates for effective work performance in the context of Malaysia.

\section{Research Methods}

\section{Modified Delphi Technique}

Delphi technique was used to gather information from a group of experts through several rounds of questionnaires to formulate a consensus among them (Delbecq, VandeVen \& Gustafson, 1975). According to Clayton (1997), the Delphi technique has three distinctive characteristics: anonymity, interaction with controlled feedback, and statistical group response. Individuals are allowed to share their views in an environment that is free of hostility, social pressure, and individual dominance as participant anonymous is generally secured during the group communication process (Andrews \& Allen, 2002). Although Delphi technique is time-consuming (Powell, 2003), it is more cost-effective when a large number of individuals are required to comprehensively investigate an issue (Linstone \& Turoff, 1975). 
In this study, a two-round modified Delphi was used to gain consensus from a group of experts about the competencies needed by future GD graduates in Malaysia. In comparison to a conventional Delphi that requests the experts to answer a set of open-ended questions in the first round, a 'modified' Delphi starts with a set of carefully selected items for them to review (Custer, Scarcella \& Stewart, 1999). These items can be created through extensive literature review, document analysis, consultation with experts, or adaptation of previously validated questionnaire (Bridges, 2013; Stahl \& Stahl, 1991; Wang, 2006). The initial competency items of the Delphi Round One of this study was produced from the review of existing literature.

\section{Delphi Panel Selection}

To ensure the quality of collected data, it is important to select the most qualified experts in the subject matter (Mullen, 2003; Ogbeifun et al., 2016). However, participant response rates have always been regarded a key concern (Hasson, Keeney \& McKenna 2000) because a Delphi study usually takes up a great deal of time (Powell, 2003). Delbecq, Van deVen, and Gustafson (1975) suggested that for experts to stay active throughout the study, they must be well-informed of the aim of the study, feel personally attached with the issue under investigation, have meaningful insights to share, and understand their contribution to the results of the research.

In this study, the experts were categorized into two groups: university-level design educators and industry practitioners. They were selected using non-probability purposive sampling technique (Cohen, Manion \& Morrison, 2000). In specific, snowball sampling technique was used to select the most suitable panel experts. According to Cohen, Manion and Morrison (2000), snowball sampling is a sampling technique where the researcher identifies a small number of individuals as key informants to recommend other qualified persons in the population to participate in the study.

22 design educators who are working at either private or public higher educational institutions (HEIs) in Malaysia, teaching bachelor's degree programmes in visual communication design, digital and interactive design, and advertising design were recruited to participate in this study. 17 industry practitioners who are from various areas such as graphic communication design, brand and identity system design, advertising design, publication design, and interactive design, were recruited with the recommendation from the board members of the Graphic Design Association of Malaysia (wREGA).. A total of 39 GD experts agreed to participate in this study.

\section{Instrumentation: Delphi Round One and Round Two}

The Delphi Round One questionnaire contained three parts. Part One consisted of a set of demographic questions. Part Two comprised a list of pre-determined competency items, which were created from the review of existing literature. The initial 125 items were classified into 33 subdomains under five competency components proposed by Cheetham and Chivers (1996; 1998), i.e., cognitive competence, functional competence, personal competence, ethical competence, and meta-competencies. A short description was given to the components and subdomains to ensure all experts were on the same page when ranking the items. The experts were requested to rank the items based on a 5-point Likert scale according to their level of importance, where: $1=$ Not at all important; 2 = Not so important; 3 = Somewhat important; 4 = Very important; and 5 = Extremely important. In addition, participants were also allowed to give comments for each item in a 'comment box'. Part Three consisted of an open-ended question for the experts to suggest any other extra competencies that should be considered by the study in Round Two.

The format and questions of the Round Two were identical to Round One. However, it only consisted of a questionnaire prompting participants to rank the competency items.

The questionnaires were designed through SurveyMonkey, an online survey development cloudbased software. Each questionnaire was examined by two experts in research methods to ensure the clarity and validity of the questions as well as the ease of use of the online survey design.

\section{Acceptance and Removal Criterion}

There is no agreed-upon consensus level in the literature for Delphi studies (Keeney, Hasson \& McKenna, 2001; Powell, 2003). Keeney, Hasson and McKenna (2001) noted that the consensus level could be guided by the significance of the topic. According to them, 100 percent consensus may be required for life and death issues, while 51 percent may be suitable for preferences.

To gain consensus among the experts to identify the most relevant competencies, a cut-off level of the items ranked 'very important' and 'extremely important' was used in this study. An item must be ranked at four or greater by at least 75 percent of the respondents. This acceptance criterion was also used in previous Delphi studies (e.g., Al-Muallem et al., 2016; Arbabisarjou et al., 2016; Johnston et al., 2014). Those items that cannot meet the acceptance criterion would be removed from the competency list eventually. However, an item would be removed 'immediately' from 
the questionnaire in Round Two if it was ranked 'not so important' or 'not at all important' by at least 75 percent of the respondents in the Round One. This is because such an item might achieve very low agreement on its level of importance or relevance among the experts who participated in this study.

Frequencies of each item were calculated by using Statistical Package for the Social Sciences (SPSS) version 21. Figure 1 illustrates the overall modified Delphi process used in this study.

\section{Results}

\section{Round One}

Round One questionnaire was accessible to all panel experts for a period of three weeks. One more week was extended to increase the response rate. Of the 39 experts who initially agreed to participate in the study, 35 responded, which yielded a total response rate of 89.7 percent. In specific, 21 (60\%) were design educators and 14 (40\%) were industry practitioners. Based on this response rate, at least 26 panel members would have had to rank a competency item at four or greater for acceptance. The overall acceptance rate in Round One was $79.2 \%$. Of the initial 125 items, 99 items were ranked 'very important' or 'extremely important' by at least 26 respondents (75\%) in Round One.

Based on the results, only one or none of the item in the following competency subdomains met the acceptance criteria: 'art and design history', 'business fundamentals', 'user-centred design skills', 'data visualisation skills', 'research skills', 'software skills', and 'design thinking skills'. This means that these subdomains might be removed from the list if the results remained the same in Round Two. None of the items in

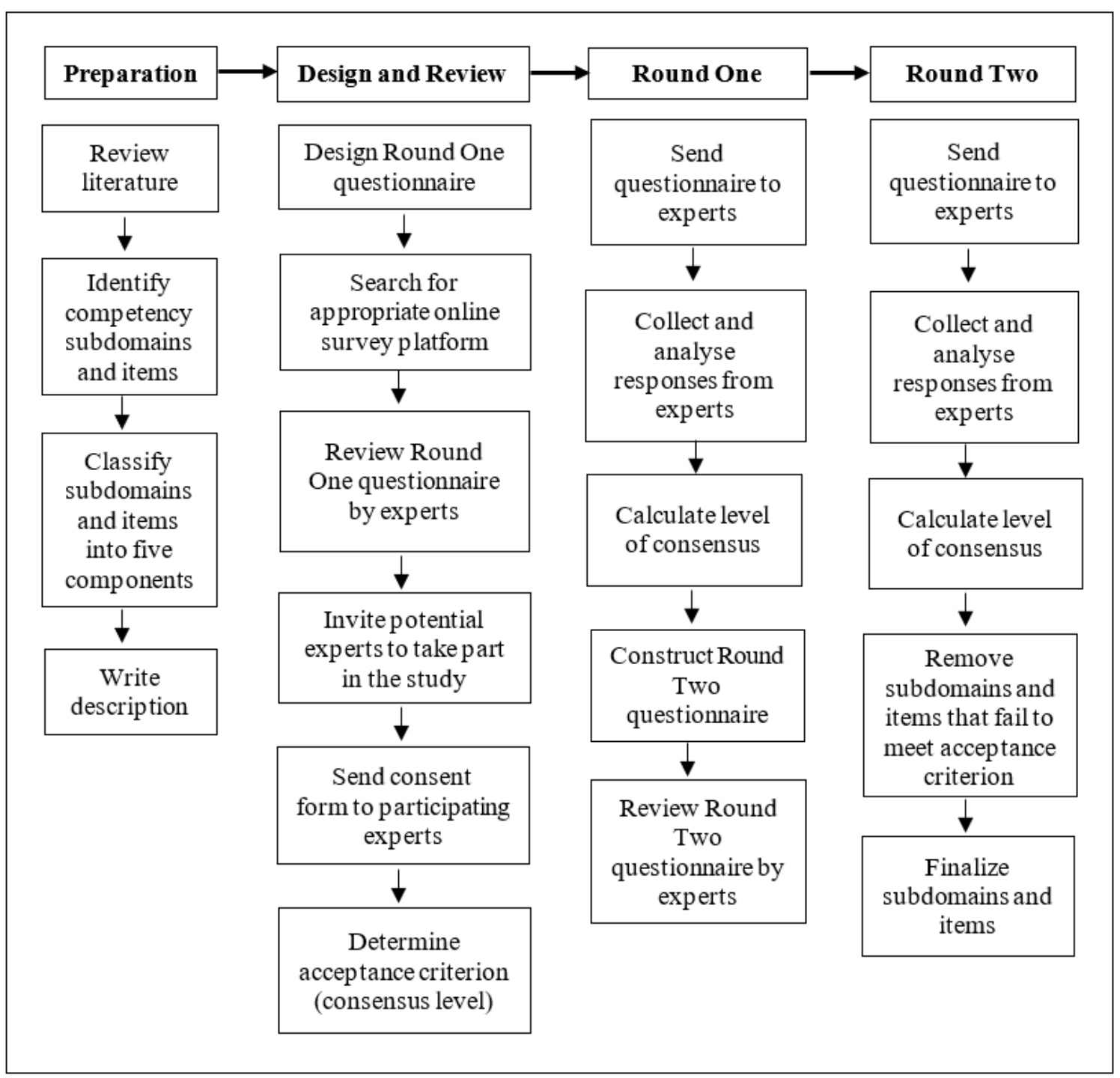

" Figure 1: The modified Delphi process used in gaining experts' consensus on competencies required by future graphic design graduates 
Round One met the immediate removal criteria. Therefore, all items were 'temporarily' included for further reviewed in Round Two. After considering the comments received in Round One, nine new items were added and 34 existing items (27.2\%) were modified. In addition, it was found that no new competency subdomain appeared from the analysis of experts' comments.

\section{Round Two}

Round Two questionnaire was accessible to all panel experts for a period of three weeks. One more week was extended to increase the response rate. 32 experts completed the questionnaire. Specifically, 19 (59.4\%) were design educators and 13 (40.6\%) were industry practitioners. This means that a competency item would have had to be ranked at four or greater by at least 24 panel members for acceptance.

Following the analysis of the Round Two, this study produced a final list of 108 competencies, which could be categorized into 29 subdomains under five competency components (Table 1).

It was worth noting that 26 items (19.4\%) were deleted after the analysis of the experts' responses in Round Two. This had resulted the removal of four competency subdomains: 'art and design history', 'user-centred design skills', 'data visualisation skills', and 'research skills'.

\section{Table 1}

Competencies for future graphic design graduates

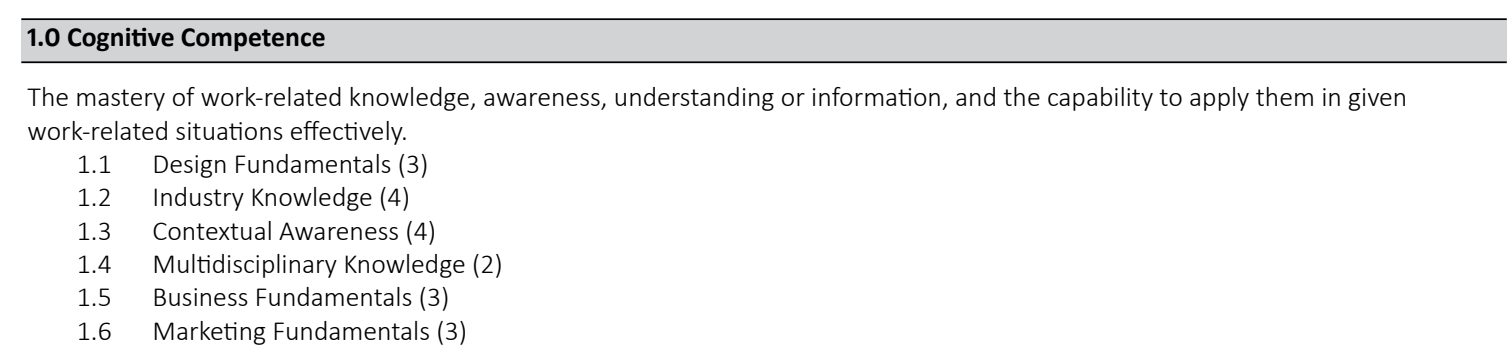

2.0 Functional Competence

The ability to successfully perform a variety of work-related tasks using available tools and technologies in order to achieve specific outcomes.
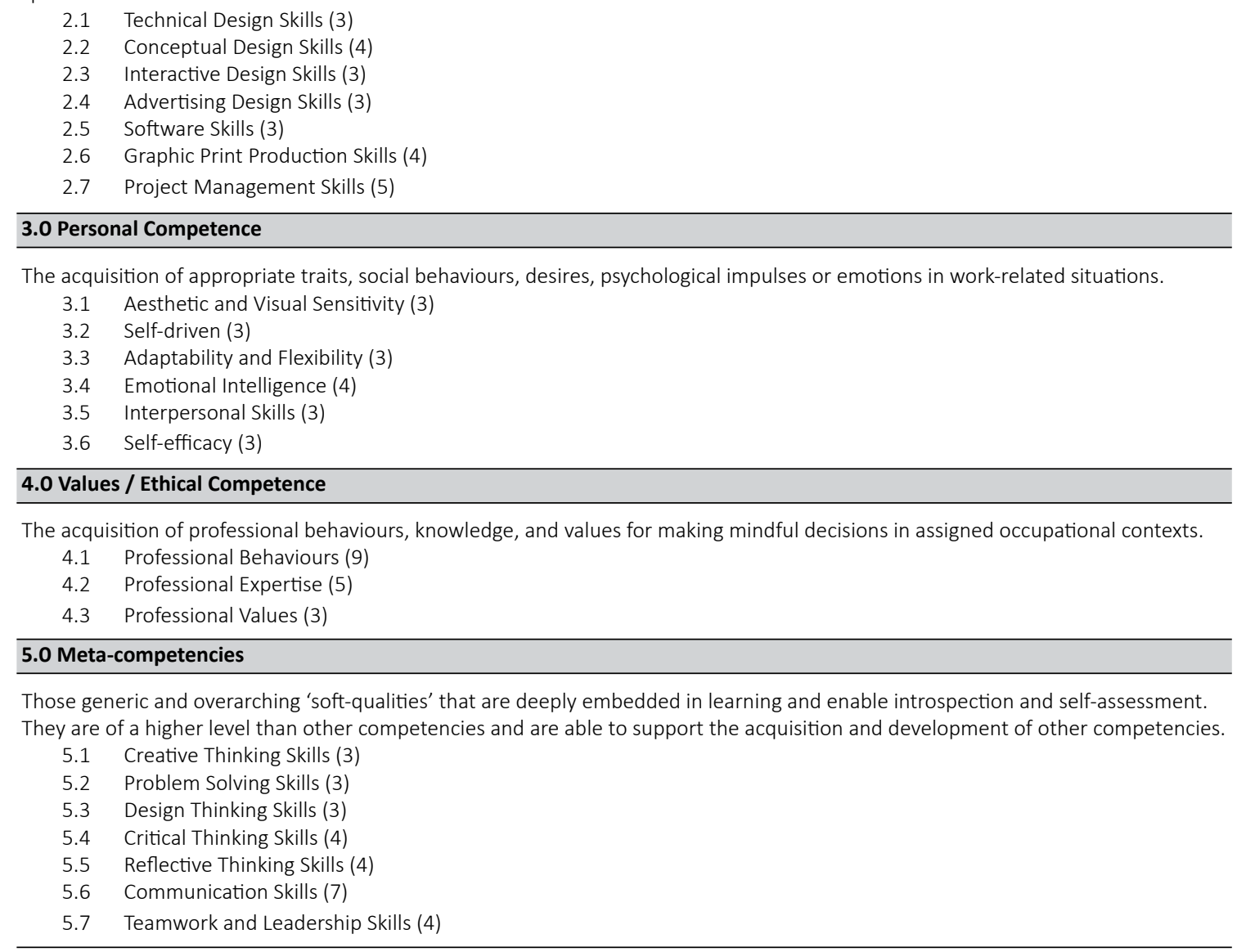


\section{Discussion}

Although collaboration between educators and industry practitioners has long been in existence, such a relationship has always been regarded as complicated. The conflict between both parties continues to be an issue, and this is not exempted in the GD discipline. Incompetent performance of graduates in the workforce is believed to be the main cause of this conflict (Bridges, 2013; Cheung, 2011). Previous studies exemplified that both parties have different expectations when it comes to what types of knowledge, skills, and abilities should be possessed by GD graduates to perform effectively in the industry (e.g., Cheung, 2016; Dziobczenski \& Galeotti, 2017; Wang, 2006). Nevertheless, it is not wise to isolate the industry's expectations from design education or vice versa (Butler, 1995). On the one hand, the realistic expectations of the industry must be considered in design education (Lewis \& Bonollo, 2002) to make sound curricular decisions (Dharavath, 2003; Wilson, 2001) and to enhance the career prospects of design graduates (Davis, 2005). On the other hand, educators are urged to fulfil not only the short-term expectations of the industry but also prepare students for the longterm needs of their lives and for making positive changes in society (Chiang, Idris \& Chuen, 2018; McCoy, 1990).

Therefore, this study aims to create a 'platform' for both parties to 'communicate' with each other to achieve some agreements regarding what competencies should be demonstrated by future GD graduates. In such a context, Delphi technique was chosen as the research method of this study. Findings showed that design educators and industry professionals in Malaysia did share similar views on the importance of certain competencies.

In general, the findings of this study echoed the results of several studies that GD graduates in the future need to be multi-skilled to begin professional practice (e.g., Adu, 2015; Dziobczenski \& Person, 2017; Dziobczenski, Person \& Meriläinen, 2018). Apart from mastering technical design skills and having good visual sensitivity, the graduates are expected to display a wide range of additional skills, knowledge, and personal traits such as industry knowledge, contextual awareness, multidisciplinary knowledge, business fundamentals, marketing fundamentals, self-driven, self-efficacy, emotional intelligence, and adaptability and flexibility to meet the changing demands in the practice. Overall, the competency subdomains and competencies uncovered provide a shared perspective among the experts in association with the intended qualities and outcomes that GD education at the university level should produce.

GD has always been related to print technology. As technology advances, interaction and user participation have become increasingly common in print design (Neves, 2017). Based on the findings, while graphic print production skills remain relevance, experts in Malaysia also expressed the importance of interactive design skills and UI and UX software skills for future graduates to catch up with the emerging trends in design. In other words, graphic designers who possess the abilities to deal with digital and interactive jobs are in more demand by the industry in Malaysia. This is in consistent with the comments or findings of several studies and reports that networked communication design and software development positions will grow in the years to come (e.g., Davis, 2017; Heller, 2015; United States Bureau of Labour Statistics, 2017). However, user-centred design skills and its related competencies, which can be used to support the interactive design process, were ranked less important by the experts, and were consequently removed from the functional competence component. It is difficult for designers to produce a satisfying and meaningful interactive experience without having skills in empathizing and evaluating the needs of end-users.

In addition, the study also found that project management skills, teamwork and leadership skills, and interpersonal skills are important to the graduates, suggesting that they may assume a more strategic or leading role in the industry in the future. Similar results had also been demonstrated in studies such as Perks, Cooper \& Jones (2005) and Valtonen (2005) on the product and industrial designers' roles. In other words, apart from fulfilling operational or outcome-related role, such as to produce physically appealing products, GD graduates will most likely be given more opportunities to participate in strategic planning for effective design solutions in the industry. In supporting of this assumption, communication skills, problem-solving skills, critical thinking skills, creative thinking skills, design and innovative thinking skills, and reflective thinking skills were also viewed as highly important by those GD experts involved in the study.

While a number of reports and studies especially in western regions had highlighted the relevance of data visualization and research skills for graphic designers to fulfil the expectations placed upon them in the future (e.g., Davis \& Littlejohn, 2017; Dziobczenski et al., 2018; Muratovski, 2016; Walker, 2017), they failed to meet the acceptance criterion and were therefore removed from the functional competence component. Moreover, history of art and design was also excluded by experts from the cognitive competence component. This reflected the concern of Heller (2005a) that the value of art and design history has often been underappreciated in the education of graphic designers. However, Hollis (2015) noted that understanding of art and design history not only gives students the confidence to think and discuss their work, it can also assist graphic designers in creating values and address questions associated with design style. Based on the findings, it can be assumed that art and design history is overshadowed by other practical competencies. It is 
a 'nice to know' but not a 'must know' area in modern design practice. This assumption can be summed up by considering a comment given by a participating expert,

It is good for [graphic] designers to 'know' or 'understand' art and design history... But I am having doubt if it is an 'important' area of knowledge that needs to be applied in the practice, especially in the context of Malaysia.

McCollam (2014) claimed that ethical aspects have often been overlooked in the education of designers, including GD. Previous studies (e.g., Chiang, 2019; Chiang et al., 2016) also suggested that from lecturers' and students' perspectives, social responsibility dimensions were not comprehensively integrated into GD curriculum in Malaysia. However, the findings of this study officially acknowledge the significance of ethical behaviours, expertise, and values in the professional practice of GD in Malaysia. For the graduates to comply with the ethical standards of the practice, they must be introduced to and aware of their responsibilities to commercial clients, other graphic designers, public, society, and environment at the university level. As noted by Berman (2013), to perform ethically in design practice "will elevate both the real and perceived value of design and designers, while helping to ensure that design is serving the social good. It's also an important step towards certification of the profession, which is ultimately what will benefit Malaysia and its designers the most" (p. 56). GD programmes providers must strive their best to identify a better way to nurture 'citizen designers' who have the abilities to produce good design (Berman, 2009, 2013; Heller \& Vienne, 2003; McCoy, 2003; Whiteley, 1993)

\section{Limitations and Recommendations}

Although this study uncovers valuable information, it does have its limitations. First, the Delphi is a very time-consuming research method (Powell, 2003); therefore, it was challenging to acquire qualified design educators and industry practitioners for this study as well as to sustain their commitment throughout the data collection process due to their hectic schedule. Although 39 experts in the field agreed to take part in this study, the highest response rate reached was in Round One, with only 35 experts completing the questionnaire. It was acknowledged by the authors of this study that it would not be appropriate to generalize the findings broadly without further validation of the identified competencies using a larger sample.

Second, very limited written feedbacks and comments were provided by the participants in Round One. Consequently, no new competency subdomains appeared in Round Two and the competency items in Round Two were almost the same with those in the Round One questionnaire.
Accordingly, more participants can be recruited in the future while conducting similar studies as the bigger the sample size, the more reliable of the Delphi studies' results (Hasson \& Keeney, 2011). With a larger sample size, it will be highly beneficial to determine the ranking of importance of the competency subdomains. In addition, though Delphi technique is proven to be a useful method to collect data for related studies, it will be interesting to use other qualitative methods such as face-to-face interview or focus group discussion to add valuable insights to the study.

It is also recommended to conduct an evaluation for university-level GD programmes using the competencies identified in this study as prescribed standards of performance. The findings can also be used as a preliminary diagnostic tool to assess the competency levels of GD students. However, additional studies should be done to further validate the findings of this study.

Lastly, as technology continues to progress, it will be necessary to ongoingly evaluate and expand the findings of this study in Malaysia and in other geographical regions. The goal of conducting related studies, as pointed out by Wang (2006), is to "impact the supply of well-educated workers, advance numerous careers, and provide students with high-quality education and potential for employment" (p. 81) in a world that is constantly changing.

\section{Conclusion}

Questions about what types of skills and knowledge should formal GD education include in courses and programmes to best prepare the graduates for professional practice in the future always become a topic of discussion and debate among design educators and industry practitioners (Dziobczenski \& Person, 2017; Kang, Chung \& Nam, 2015). As noted previously, both parties are important stakeholders in the educational and employability process of graphic designers, but their objectives and missions are fundamentally different (Cheung, 2011). At the same time, the changing nature of the workplace, coupled with changes in the global economy, society, technology, and people's behaviour has diversified the career pathways for graphic designers in the industry (AIGA, 2015b; Dziobczenski et al., 2018), requiring them to possess a broad range of new competencies, including those outside of design disciplines and fields (Davis, 2015; Kiernan \& Ledwith, 2014; Nae, 2017). The traditional understanding of design has its limitations in a rapidly changing world and therefore must be re-examined (Davis, 2008).

However, empirical studies on GD discipline (Logan, 2006) and the professional practice of graphic designers (Van der Waarder, 2009) remain limited. Therefore, the competency subdomains and com- 
petencies unveiled by this study through a collective of educators and practitioners provide valuable insights on the skills and knowledge in GD graduates required by future employment market.

Overall, the competency subdomains and competencies span a number of different areas, covering some that are typically addressed and those that are newly identified. Good personal traits and ethical awareness were perceived by experts as highly relevant for effective work performance in the GD field. The findings posed immediate challenges to design educators and HEls in developing the most relevant curricula to help their students to secure a position within a changing professional environment. Apart from focusing on the technical expectations for entry-level employment, design educators may want to prepare students for more senior positions by training them to work in a more integrative and strategic way. New areas of expertise such as project management, teamwork and leadership, and interpersonal skills, should be integrated into different courses in the programmes. Design educators are challenged to introduce these areas to students in the context of design effectively. For industry practitioners and design companies, the findings of this study provide a basic structure or prescribed standards of performance for them in recruiting, selecting, developing, training, and evaluating their teams. In addition, it is hoped that these insights can be used to differentiate professionally trained graphic designers from those informally trained and to enhance the status of GD as a profession.

As technological developments in the GD industry are currently changing many of the job descriptions, there is a greater need for a qualified workforce (Dharavath, 2003). GD educators and practitioners need to work closely to equip the graduates with the competencies required for effective job performance. Such relationship can be established through classroom and curricula activities, intensive design workshops, advisory boards, professional conferences and organizations, design competitions, employment or internship opportunities, student and faculty on-site opportunities, corporate-sponsored research projects, corporate grants, and so on (Roberts, 2007). A new model should be developed to encourage better collaboration between design educators and practitioners.

\section{References}

Adu, A. (2015) Graduate employability: The link between design education and the graphic design industry. Kwame Nkrumah University of Science and Technology, Kumasi, Ghana.

Al-Muallem, A., Elzubeir, M., Roberts, C. \& Magzoub, M. (2016) Development and Initial Testing of an Instrument for Evaluating Needs and Inferring Readiness of
Research Supervisors: A Mixed Methods Approach. Health Professions Education. 2 (2), 138-147. Available from: doi: 10.1016/j.hpe.2016.03.001

American Institute of Graphic Design (AIGA) (2010) AIGA Standards of professional practice. New York, Aiga, Available from: aiga.org/resources/aiga-standards-of-professional-practice [Accessed: $27^{\text {th }}$ December, 2018]

American Institute of Graphic Arts (AIGA) (2015a) Designer of 2015 competencies. New York, AIGA, Available from: http://www.aiga.org/designer-of-2015-competencies/ [Accessed: $27^{\text {th }}$ December 2017]

American Institute of Graphic Arts (AIGA) (2015b) Designer of 2015 trends. New York, AIGA, Available from: http://www.aiga.org/designer-of-2015-trends [Accessed: 27th December 2017]

Andrews, C. G. \& Allen, J. M. (2002) Utilization of technology-enhanced Delphi techniques. Workforce Education Forum. 29 (1), 1-15.

Arbabisarjou, A., Siadat, S. A., Hoveida, R., Shahin, A. \& Zamani, B. E. (2016) Managerial competencies for chairpersons: A Delphi study. International Journal of Humanities and Cultural Studies. 3(1), 1634-1645.

Berman, D. (2009) Do Good Design. California, AIGA \& New Riders.

Berman, D. (2013) A dialogue with David Berman. Cut Out Magazine, pp. 54-57.

Bridges, A. W. (2013) Identification of perceived 21st century graphic design skills, content knowledge, and tools needed in an effective university-level graphic design program. EdD thesis. Gardner-Webb University.

Butler, J. (1995) The process for effective graphic design curriculum development. Madison, University of Wisconsin-Madison.

Cheetham, G. \& Chivers, G. (1996) Towards a holistic model of numeracy competence. Jorunal of European Industrial Training. 20 (5), 20-30. Available from: doi: 10.1108/03090599610119692

Cheetham, G. \& Chivers, G. (1998) The reflective (and competent) practitioner: A model of professional competence which seeks to harmonise the reflective practitioner and competence-based approaches. Journal of European Industrial Training. 22 (7), 267-276. Available from: doi: 10.1108/03090599810230678

Cheung, B. P. S. (2011) Double 'Blind Spots' of the academia and design industry. In: BODW: Proceedings of DesignEd Asia Conference 2011, 29-30 November 2011, Hong Kong, China. Hong Kong, The Hong Kong Polytechnic University.

Cheung, B. P. S. (2016) Professional graphic design knowledge in Hong Kong: From graduate to professional. Communication Design. 4 (1-2), 21-40. Available from: doi: 10.1080/20557132.2016.1275476

Chiang, W. S. (2019) Lecturers' understanding of integrating social responsibility dimensions into graphic design curriculum?. Journal of Education and Social Sciences. $2(2), 12-26$.

Chiang, W. S., Idris, M. Z. \& Chuen, T. W. (2019) Is graphic 
design being taken seriously as a profession?. Journal of Arts and Social Sciences. 3 (1), 1-9.

Chiang, W. S., Idris, M. Z. \& Chuen, T. W. (2018) What makes an undergraduate graphic design education valuable?. Journal of Education and Social Sciences. 11 (1), 73-82.

Chiang, W. S., Al-Hudawi, S. H. V., Hamdam, A. R. \& Musah, M. B. (2016) Students' understanding of integrating social responsibility dimensions into graphic design curriculum?. Man in India. 96 (1-2), 547-566.

Clayton, M. J. (1997) Delphi: A technique to harness expert opinion for critical decision-making tasks in education. Educational Psychology. 17 (4), 373-386. Available from: doi: 10.1080/0144341970170401

Cohen, L., Manion, L. \& Morrison, K. (2000) Research methods in education - 5th edition. New York, Routledge Falmer.

Custer, R. L., Scarcella, J. A. \& Stewart, B. R. (1999) The Modified Delphi Technique- A Rotational Modification. Journal of Career and Technical Education. 15 (2), 50-58. Available from: doi: 10.21061/jcte.v15i2.702

Davis, M. \& Littlejohn, D. (2017) Accountability for anticipating design outcomes. New York, AIGA, Available from: https://www.aiga.org/aiga-design-futures/ accountability-for-anticipating-design-outcomes/ [Accessed: 12th February 2019]

Davis, M. (2005) Raising the bar for higher education. In: Steven, H. (Ed.) The education of a graphic designer 2nd edition. New York, Allworth Press, pp. 13-18.

Davis, M. (2008) Why do we need doctoral study in design?. International Journal of Design. 2 (3), 71-79.

Davis, M. (2015) Interdisciplinarity and the education of the design generalist. In: Steven, H. (Ed.) The education of a graphic designer - 3rd edition. New York, Allworth Press, pp. 20-29.

Davis, M. (2017) Introduction to Design Futures. New York, AIGA, Available from: https://www.aiga.org/ aiga-design-futures/introduction-to-design-futures/ [Accessed: 12th February 2019]

Debbie, G. S. S. (2011) A nation's visual language: Nation branding and the visual identity of contemporary malaysia. PhD thesis- partial. Nottingham Trent University.

Delbecq, A. L., VandeVen, A. H. \& Gustafson, D. H. (1975) Group techniques for program planners: A guide to nominal group and Delphi processes. Glenview, Scott, Foresman \& Co.

Dharavath, H. N. (2003) Importance of technical competencies in the graphic communications technology curriculum as perceived by the graphic communications industry and educators. Journal of Industrial Technology. 19 (2), 1-7.

Dziobczenski, P. R. N. \& Galeotti, A. A. R. (2017) Preparing design students for the market: An initial investigation on the required knowledge and skills for graphic designers in Brazil. The Design Journal. 20 (sup1), S1241-S1249. Available from: doi: 10.1080/14606925.2017.1352653

Dziobczenski, P. R. N. \& Person, O. (2017) Graphic design- er wanted: A document analysis of the described skill set of graphic designers in job advertisements from the United Kingdom. International Journal of Design. 11 (2), 41-55.

Dziobczenski, P. R. N., Person, O. \& Meriläinen, S. (2018) Designing career paths in graphic design: A document analysis of job advertisements for graphic design positions in Finland. The Design Journal. 21 (3), 349-370. Available from: doi: 10.1080/14606925.2018.1444874

Dziobczenski, P. R. N., Person, O., Tonetto, L. M. \& Mandelli, R. R. (2018) Requests from companies and requirements for design education in Brazil: Where do they meet?. In: DRS 2018, Design Research Society International Conference, Catalyst, 25-28 June 2018, Limerick, Ireland. Limerick, University of Limerick. pp. 2823-2835. Available from: doi: 10.21606/ drs.2018.535

Eraut, M. (2007) Early career learning at work and its implications for universities. Student Learning and University Teaching, British Journal of Educational Psychology (BJEP), Monograph Series. 11 (4), 113-133.

Frascara, J. (1988) Graphic design : Fine art or social science?. Design Issues. 5 (1), 18-29. Available from: doi: $10.2307 / 1511556$

GDC (2012) Code of ethics and professional conduct for graphic designers. Ottawa, GDC. Available from: https://gdc.design/code-of-ethics [Accessed: 1st June, 2021]

Harland, R. (2016) Graphic Design in urban environments. London, Bloomsbury Academic.

Hasson, F. \& Keeney, S. (2011) Enhancing rigour in the Delphi technique research. Technological Forecasting and Social Change. 78 (9), 1695-1704. Available from: doi: 10.1016/j.techfore.2011.04.005

Hasson, F., Keeney, S. \& McKenna, H. (2000) Research guidelines for the Delphi survey technique. Journal of Advanced Nursing. 32 (4), 1008-1015. Available from: doi: 10.1046/j.1365-2648.2000.t01-1-01567.x

Heller, S. \& Vienne, V. (2003) Citizen designers: Perspectives on design responsibility. New York. Allworth Press.

Heller, S. (2015) The education of a graphic designer - 3rd edition. New York, Allworth Press.

Heller, S. (2005a) The education of a graphic designer. In: Choice Reviews Online - 2nd edition. New York, Allworth Press.

Heller, S. (2005b) Too many grads or too few competencies? The design school dilemma. New York, Aiga. Available from: www.aiga.org/too-many-grads-or-too-fewcompetencies-the-design-school-dilemma [Accessed: 27th December, 2017]

Higgins, B. (2008) Program evaluation: Utilizing graduate and employer perception data in determining graduates'job preparedness levels. Journal of Industrial Technology. 24 (3).

Hollis, R. (2015) Principles before style: Questions in design history. In: Heller, S. (Ed.) The education of a graphic designer - 3rd edition. New York, Allworth Press, pp. 144-146. 
Hsieh, S. F., Guan, S. S. \& Wu, C. L. (2010) The study on competency of graduating students being major in graphic design. International Journal of Learning. 17 (9), 389-402.

International Council of Design (ico-D) (2011) Best practice paper: Model code of professional conduct for designers. Montréal, ico-D.

Johnston, L. M., Wiedmann, M., Orta-Ramirez, A., Oliver, H. F., Nightingale, K. K., Moore, C. M., Stevenson, C. D. \& Jaykus, L. A. (2014) Identification of Core Competencies for an Undergraduate Food Safety Curriculum Using a Modified Delphi Approach. Journal of Food Science Education. 13 (1), 12-21. Available from: doi: 10.1111/1541-4329.12024

Kang, H. J., Chung, K. W. \& Nam, K. Y. (2015) A competence model for design managers: A case study of middle managers in Korea. International Journal of Design. 9 (2), 109-127.

Keeney, S., Hasson, F. \& McKenna, H. (2001) A critical review of Delphi as a research methodology in nursing research. International Journal of Nursing Studies. 38, 195-200.

Kiernan, L. \& Ledwith, A. (2014) Designers for the of product design graduates in Ireland. The Design Journal. 17 (2), 218-237. Available from: doi: 10.2752/175630614 X13915240576022

Lewis, W. P. \& Bonollo, E. (2002) An analysis of professional skills in design: Implications for education and research. Design Studies. 23 (4), 385-406. Available from: doi: 10.1016/S0142-694X(02)00003-0

Lim, B. (2015) A discussion on creativity and design education in Singapore and Malaysia. Journal of Research in Humanities and Social Sciences. 3 (2), 56-61.

Linstone, H. A. \& Turoff, M. (1975) The Delphi method: Technique and applications. Reading, Addison-Wesley Educational Publishers, Inc.

Logan, C. D. (2006) Circles of practice: educational and professional graphic design. Journal of Workplace Learning. 18 (6), 331-343. Available from: doi: 10.1108/13665620610682062

Marks, A. (2015) A design core for the twenty-first century. In: Heller, S. (Ed.) The education of a graphic designer-3rd edition. New York, Allworth Press, pp. 17-19.

McCollam, P. (2014) Redefine design ethics: Why. Design and Culture. 6 (3), 315-325. Available from: doi: 10.27 52/175613114X14105155617384

McCoy, K. (1990) Professional design education: An opinion and a proposal. Design Issues. 7 (1), 20-22.

McCoy, K. (2003) Good citizenship: Design as a social and political force. In: Heller, S. \& Vienne, V. (eds.) Citizen designers: Perspectives on design responsibility. New York, Allworth Press, pp. 2-8.

Mullen, P. M. (2003) Delphi: Myths and reality. Journal of Health Organization and Management. 17 (1), 37-52. Available from: doi: 10.1108/14777260310469319

Muratovski, G. (2016) Research for designers: A guide to methods and practice. California, SAGE Publications Inc.
Nae, H.-J. (2017) An Interdisciplinary Design Education Framework. The Design Journal. 20 (sup1), S835-\$847. Available from: doi: 10.1080/14606925.2017.1353030

Neves, M. (2017) The future of print design relies on interaction. The Design Journal. 20 (sup1), S4087-\$4100. Available from: doi: 10.1080/14606925.2017.1352910

Ogbeifun, E., Agwa-Ejon, J., Mbohwa, C. \& Pretorius, J. H. C. (2016) The Delphi technique: A credible research methodology. In: Proceedings of the 2016 International Conference on Industrial Engineering and Operations Management, 8-10 March 2016, Kuala Lumpur, Malaysia. IEOM Society International. pp. 2004-2009.

Okyere, M. (2017) The graphic design workforce in Ghana: a case study of Asafo, Kumasi. Communication Design. 5 (1-2), 183-202. Available from: doi: 10.1080/20557132.2017.1398926

Perkins, S. (2011) Ethics and Social Responsibility?. New York, AIGA. Available from: https://www.aiga.org/ethics-and-social-responsibility [Accessed: $27^{\text {th }}$ December, 2018]

Perks, H., Cooper, R. \& Jones, C. (2005) Characterizing the role of design in new product development: An empirically derived taxonomy. Journal of Product Innovation Management. 22 (2), 111-127. Available from: doi: 10.1111/j.0737-6782.2005.00109.x

Powell, C. (2003) The Delphi Technique: Myths and realities. Methodological Issues in Nursing Research. 41 (4), 376-382.

Roberts, J. (2007) The future of academic-industry collaboration. International Association of Scieties of Design Research. 1-17.

Stahl, N. N. \& Stahl, R. J. (1991) We can agree after all! achieving consensus for a critical thinking component of a gifted program using the delphi technique. Roeper Review. 14 (2), 79-88. Available from: doi: 10.1080/02783199109553392

Swanson, G. (2015) Design and knowledge in the university and the "real world ". In: Heller, S. (Ed.) The education of a graphic designer - 3rd edition. New York, Allworth Press, pp. 33-43.

United States Bureau of Labour Statistics (2017) Employment Projections - 2016-26. BLS: Available from: https://www.bls.gov/news.release/pdf/ecopro.pdf [Accessed: $15^{\text {th }}$ January, 2019]

Valtonen, A. (2005) Six decades - and six different roles for the industrial designer. Available from: https://pdfs.semanticscholar.org/d1d7/ 479861c9a83c223e35dd5b95c9c26cda5d9c. pdf?_ga=2.215739095.1369317459.1566194522431526288.1566194522 [Accessed: $18^{\text {th }}$ January, 2018]

Van der Waarder, K. (2009) On graphic design: Listening to the reader?. Research Group Visual Rhetoric.

Walker, S. (2017) Research in Graphic Design. The Design Journal. 20 (5), 549-559. Available from: doi: 10.1080/14606925.2017.1347416

Wang, S.-Y. (2006) Identification of the significant competencies in graphic design. PhD thesis. University of 
Missouri-Columbia.

Whiteley, N. (1993) Design for society. London, Reaktion Books Ltd.

Wilson, G. D. (2001) Needs assessment: Implications for graphic communications education. Visual Communications Journal, 1-6.

Wilson, R. G. (2014) Curriculum \& course design: Preparing graphic design \& visual communication students. MFA thesis- partial. lowa State University.

WREGA (2012) Code of professional conduct (COPC)? Kuala Lumpur. wREGA. Available from: http://www.wrega. org/legal.html [Accessed: $1^{\text {st }}$ June 2021]

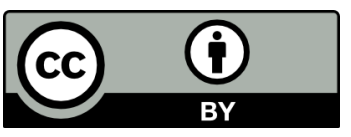

(C) 2021 Authors. Published by the University of Novi Sad, Faculty of Technical Sciences, Department of Graphic Engineering and Design. This article is an open access article distributed under the terms and conditions of the Creative Commons Attribution license 3.0 Serbia (http://creativecommons.org/licenses/by/3.0/rs/). 